\title{
AN ANALYTICAL EVALUATION OF THE SCHOOL LIBRARY HOME PAGE IN JAPANESE SECONDARY SCHOOLS
}

\author{
Mieko Nagakura \\ Instructor \\ Correspondence Education Division \\ Soka University \\ Japan
}

The content analyses of 151 school library home page in Japanese secondary schools were carried to examine their possibility and effectiveness as an instructional tool for information literacy development of the students. The possibility was proved, but the effectiveness was not verified by this study. The contentwise, secondary school library home page was informative, cultural, and instructive. The contents on junior high school level were mostly informative, while the contents on integrated junior/senior and senior high school levels were informative as well as instructive. Link collections were the most powerful features of school library Website.

\section{INTRODUCTION}

In the past few years, the spread of mobile phones and computers among young people, and popular use of the Internet at home have been quite significant in Japan. Computer connections to the Internet were realized at every school by the end of 2001, while instructions of information literacy have been established as a compulsory subject in the curriculum of general course senior high schools since 2003.

Under such circumstances described above, it may be possible to expect that library home page (The term, Website is used interchangeably in this paper) can be appropriate measures for students to learn information skills on their own and to improve their demonstration or expression of research and study results much better than the students who are not available to reach their own school library websites.

This study is planned to prove above hypothesis by reviewing and evaluating the contents of library home page which presently appear on the Internet as the Websites of public and private secondary (e.g. junior, senior and integrated) schools. At the preliminary stage of the study, a framework was formulated so as to describe and evaluate the effectiveness of library home page as an information literacy instructional tool.

The search engine, Yahoo Japan, was thoroughly used to collect and extract sample home page in the lights of region, gender, school level, and social and educational environments. Collection and extraction of samples had been carried out in September 2006, but it was done again in February and March 2007, bearing the updates of sample home page in mind. Total school library Websites reviewed in this study are 363. Out of these, 151 Websites were analyzed by their contents. 
In order to collect study samples, two kinds of method were used. For the local focus sampling, it was decided to treat two contrasting areas; Tokyo Metropolis and Tokushima Prefecture (Prefecture is comparable to "state" or "province"). Tokyo is the nation's capital and the most overpopulated city, while Tokushima Prefecture is sparsely populated area in Shikoku Island with very small population of school age children. For another survey, the samples were collected nationally from different school levels.

\section{FRAMEWORK OF SCHOOL LIBRARY HOME PAGE}

By scanning through all samples, it was found that their contents could be roughly categorized into 4 groups by function. They were informative, instructive, cultural, and comprehensive. Informative function is almost the same as school library bulletin board on the Web or BBS, while instructive function is similar to the function of simple CAI program. Cultural function means to foster the cultural background of students and teachers. Comprehensive function is the integration or the multiple of foregoing three functions.

Minding the functions mentioned above, the most exhaustive contents of school library home page are listed below with actual work items as a standard framework to examine Websites. In the following framework, communicative function is comparable to the mixture of cultural and informative functions.

\section{Standard Framework of School Library Home Page}

(1) Informative functions

Library User's Guide:

Library hours, Circulation rules, Library map or Shelf arrangement guide, OPAC, Library manners

What's New:

Latest issues of subscribing magazines, New acquisitions of book, CD and DVD, Library bulletin, New library publications, Library topics

(2) Communicative functions

Library notice, On-line exhibitions such as pictures of reading impression, Book reviews by students and teachers, Personal introduction of library staff, Reports of library events, Schedule of library events, Library calendar, Annual schedule of school library club activities, Annual schedule and report of the student library committee, Lists of recommended books

(3) Instructive functions

User's education such as "netiquette", Study skills such as "How to write good reports and papers", Information retrieval techniques, CD-ROM servers, Direct links to resourceful Websites, Links to other library's OPAC, Search engines, Answers to typical reference questions, Acceptance of personal reference questions

\section{LOCAL FOCUS SURVEY}

\section{Secondary Schools in Tokyo Metropolis}

Both thorough and sampling survey systems were used for searching appropriate school library home page from Tokyo area. The thorough survey system was applied to 
public senior high schools, while sampling survey system was adopted to extract the Websites from different kind of secondary schools. For thorough survey, the Websites of all public senior high schools were reviewed so as to check whether they have library page or not. For sampling survey, Yahoo Japan was used to locate and extract the well-designed school library home page with searching terms of "high schools", "library", "Tokyo". The results of both surveys are reported in the following sections.

Thorough Survey. Tokyo Metropolitan Government Board of Education directly runs 200 public senior high schools, excluding special and part-time education schools. In 2003, the Board had provided each public school at the minimum of $10 \mathrm{MB}$ on the government server to open school home page, and so presently all public senior high schools in Tokyo have their own Websites. As for the Website contents, the Board did not set any restrictions that every school built their own home page, showing each school's originality and attractiveness.

After reviewing 200 Websites, it was found that 104 schools (52\%) referred to the existence of their libraries. However, 94 schools did not provide any information other than the library existence. Out of 104 schools, the majority e.g. 73 schools (69\%) placed their library information under the head of "facilities and equipments" at the top page menu or index of their school Websites. Only 18 schools facilitated independent "library" icon at the top page index. Without knowing the fact that Japanese education system classifies a library as a school facilities/equipments instead of an educational agency, students as well as teachers are unable to reach their library information on the Web.

The most frequently used pattern for introducing library on the Web was colourful photos of library scenes with or without captions. The Websites of 23 schools (22\%) placed only one piece of library photo along with the photos of other facilities, such as gymnasium, auditorium, classrooms, and science and cooking laboratories. The Websites that used 2 pieces of library photo were 3 . Out of 3,2 without captions, one with captions and size of library book stock. One Website used 5 pieces of photo to introduce its library with a few words of explanation.

Another typical pattern to introduce library was a reference on the table of school facilities. 22 schools (21\%) listed their library as an item on the table; 17 listed library without any additional information, 3 with the library room size, and 2 with short description of library service.

Simple introduction of school libraries, such as reading room size, volumes of library stock, and seating capacity, were appeared on the home page of 7 schools. Without referring to their libraries, the Websites of 2 schools only referred to the activities of student library committees. The Website of another school frequently referred to the library activities in the principal's monthly report. Without referring to their own school libraries, the Websites of 2 schools had the links to neighborhood public libraries, useful search engines, electronic dictionaries, and educational computer games.

In general, the contents of school library home page are informative in nature at Tokyo metropolitan senior high schools. It seems that the purpose of putting up school library home page is to give the basic information for the parents and students of junior high schools who are going to make their choices of entering senior high schools. 
Sampling Survey. There are 36 samples of school library Website, which have been extracted from Tokyo Metropolitan area for this study. The samples are composed of 25 public and 2 private senior high, 1 public junior high, and 8 private integrated junior/senior high schools. Through the sampling survey, it became clear that private integrated course schools built the most of well-designed library Websites. This phenomenon can be proved by the fact that there are only one sample $(2.7 \%)$ from public junior high school and $2(5.5 \%)$ from private senior high school, comparing to $8(22.2 \%)$ private integrated course schools.

Only one sample of public junior high school is Mitaka Municipal Daini Junior High School. (http://www.education.ne.jp/miyaka/nichu-jh/toshokan/top.html) Mitaka city is the most democratic and cultural district in Tokyo. Mitaka Municipal Board of Education has established the network of public schools, which offers the OPAC of every public school library on the Web. On every Saturday morning, all school libraries in the city are open to the public, and so any citizens, irrelevantly to the parenthood of students, are able to use and borrow school library books. They are also able to use library computers for the Internet search, and to enjoy video viewing freely.

The home page of Mitaka Daini Junior High School is simple, but well designed for junior high students. It is illustrative and beautiful with much application of clipart as well as colourful photographs. The top page contents are composed of (1) the welcome message to the library, (2) short introduction of library purpose, functions, and services, and (3) the Website index. The followings are the index headings: (1) basic library information, (2) library user's guide, (3) searching of OPAC on the municipal school library network, (4) Library in This Month; monthly library exhibits, the library monthly bulletin, new library acquisitions, and (5) information for public opening; library calendar and rules for community users. The basic library information refers to the renewal of library facility as the study and information centre of the school in 2001, the library holdings as of December 2006, and the size of library room, e.g. $234 \mathrm{~m}^{2}$. The library user's guide contains library hours for students as well as for citizens, circulation rules of library books, reference services, requests for acquisitions, rules for computer use, and library user's manner. The library exhibits are introduced by colour photos, while monthly library events and notices are announced in the monthly bulletin.

Generally speaking, the Web pages of Mitaka Daini Junior High School Library are more informative, and less instructive in nature. However, they are attractive enough to lure students and citizens to the library and to promote their free voluntary reading activities.

The review and evaluation of the library Websites from 8 private integrated junior/senior high schools in Tokyo will be treated later in the chapter of integrated junior/senior high schools at the national focus study, together with other Website samples from different areas.

\section{Secondary Schools in Tokushima Prefecture}

Tokushima Prefecture Board of Education has been confronted with difficult problems to counteract rapid declining of children's population in the area as well as to keep quality education in schools economically. One solution to the problem is the promotion of elearning, and the other is to reorganize public school system especially on the secondary level. In August 2004, the Board organized the Committee on Reformation of the Prefectural High 
School Education System. The final report of the Committee suggested the realignment of secondary school system, so as to attain the reasonable quota of 160 students at each school, and to create new types of secondary schools that are able to foster dreams and hopes of every young people. The Board immediately put the Committee's recommendations in action. Vocational senior high schools in sparsely populated area were combined with general senior high schools in vicinity, and some senior high schools were integrated with junior high schools. Such newly formed comprehensive or integrated course schools were well equipped with IT apparatus.

Even today, the reorganization of secondary school system is in progress. At this moment, there are 44 senior high schools in Tokushima Prefecture, of which 40 are public and 4 are private schools. The total number of junior high schools are 99, of which 96 are public, 2 are private, and one is national.

Since the total number of schools in the prefecture is not large, the thorough survey system was applied to review the contents of school library home page at junior as well as senior high school level. In the following, the results of thorough survey are reported by school level.

Junior High Schools. Contrary to the author's expectation, only $52.2 \%$ of junior high schools carry their Websites on the Internet. After reviewing all school Websites, it was found that only 2 Website provide school library home page, and 6 Websites simply refer to the existence of their libraries. A private school Website placed two pieces of library photo in the file of school buildings, while another public school put two pieces of library photo accompanying the activity report of student library committee. In the school guidebooks carried on the Web, one public school listed its library as a segment of building management, and another public school introduced library service with reference to the morning read-in program of which Japanese term is Asa-dokusho. Without referring to the library, one school Website provided 2 photos of Asa-dokusho scene with captions. On another Website, the student library committee was named on the organization chart of the student council with no reference to school library. One school Website indicated the location of library room on the campus map.

The well designed library home page was found at the Website of Miyoshi Municipal Yamashiro Junior High School. This junior high school is located in the underpopulated mountainous district, of which municipality has just formulated by the integration of 3 towns and 2 villages in 2006. At the time of municipal inauguration, the school library was installed in a new extension of the old school building, and also the community hall was set as an annex to this new extension. The contents of library home page at Yamashiro Junior High School are as follows:

\section{Library Guide}

- Library stock (about 3000 volumes)

- Daily library hours (12:50 13:20)

- Library book loan period and volumes (1 volume for 2 weeks)

- Procedures to borrow library books

- Library management body: Student Library Committee

- Shelving system (Japan or Nippon Decimal Classification System; NDC)

- Special sections: magazines, reference books, and the special collection

Library Monthly Bulletin: Click to open the files of all published issues.

Delivery Service to Classroom Collection 
Book Talks; each member of the Student Library Committee would give book talks in turn at the school assembly meetings.

$\diamond$ Special Collection; the collection donated by the school songwriter. $\underline{\text { Click to open its }}$ OPAC.

$\diamond$ Reading Marathon or Long Term Individual Reading Program. Click to open the followings.

- What is Reading Marathon; introduction with the activity rules and colour photos.

- Reports of Reading Marathon

* Return buttons to the top of library and school home page.

\section{Author Visit Project}

- Inviting messages to the author who would give lectures at the school. $\underline{\text { Click to }}$ open message files.

- Five questions to the author who gives lectures at the school. Click to open question files.

* Return button to the top of library home page.

\section{Asa-dokusho or Read-in Program in the Morning Hour (8:24a.m. 8:35a.m.)}

- Reports of 4 typical class activities with color photos: Link to Five Rules of Asa$\underline{\text { dokusho }}$

- Activity reports from each school class: Links to the report files of all classes.

\section{Reading Survey: Click to open the following files.}

- Questionnaire format

- Survey results

- Evaluation and analysis of survey results

* Return buttons to the top of library and school home page.

The School Report of Reading Guidance through Library Activities at Yamashiro Junior High School

$\diamond$ Reading Aloud Program in the Morning Hour; weekly book reading service by community volunteers. Click to open the files of reactions and appreciations by students, with color photos.

* Return buttons to the top of library and school home page.

http://www.mkk.ed.jp/yamachu/siteyamachu/index.html

Integrated Junior/senior High Schools. The Website of Tokushima Prefectural Jounouchi High School carries very good school library home page. This school is an integrated junior and senior high school in Tokushima city that had established in 2004 under the reformation of high school system. The components of this home page are as follows:

Message from the Library: The encouragement for students to foster their personality through the reading during the six years at high schools.

$\diamond$ Announcements from the School Librarian:

- Reports of the reading circle meetings. $\underline{\text { Click to open the report videos. }}$

- Notice of the coming reading circle meeting. Click to open the detail, e.g. date, place, and discussion theme.

- The librarian's report on the National Annual Library Conference. Click to open the video recording of the main speech by a famous adolescent author.

- Annual ranking of the favourite books loaned out from the library.

- Attentions to overdue books.

Library Guide:

- Library hours. 
- Rules for borrowers; loan periods, renewal, non-circulating materials, etc.

- Searching of OPAC; search methods, time limitations, etc.

- Requests and reservations of library books.

- Rules for the use of videos; viewing in the library, taking out of the library.

- Rules for the individual use of the Internet.

The Library History: 1980 2004.

Library Floor Plan and Photo Introduction of Library Corners and Equipments.

- Floor plan with area size and seating capacity

- 15 pieces of colour photo

Library Holdings:

- Books tabulated by NDC, in comparison with the National Standard of School Library Book Stock.

- List of subscribing magazines (19 titles)

- List of subscribing newspapers (4 titles)

- Book sets for group readings (50 volumes for each set); recommended books by Japan School Library Association, classics, paper backs, sex education, human rights education, etc.

- Special collections

- Clippings of newspaper articles

- List of cassette tape holdings

- List of video software (DVD) holdings, with subject classification.

Special Windows; Click to open the following files.

- Activities of the Student Library Committee; book exhibits, publication of the library bulletin and newspaper, reading circle and lecture meetings, shelf reading, circulation service, etc.

- Recommended books; 100 titles of assigned reading for senior high school students and 100 titles for junior high school students

Colour Photos of Library Scene

- School librarian at the desk, book browsing by girls, independent study, etc. http://www.johnouchi-hs.tokushima-ec.ed.jp/toshokan/toshokan.htm

Both of the library home page introduced above are very well designed, and have attractive configurations for junior high school students who love to click link buttons and to view colorful images in motion. Their contents are mostly informative in nature and heavily place emphasis on reading guidance and its promotion. At both Websites reviewed, there are no contents that instruct the skills of information search and retrieval as well as the basic knowledge to cope with highly developed information society.

Senior High Schools. Every 40 public senior high schools in Tokushima Prefecture carry their home pages on the Internet. After reviewing all 40 Websites, it was found that 10 $(25 \%)$ Websites were placing their library information. Six schools provided "library" icon at the top page index. By clicking "library" icon, the author was able to reach 5 library Web pages. One Website with "library" icon on index page presented only the tabulation of library book stock, which was sorted by 10 main classes of NDC. Another school Website indicated "Asa-dokusho" icon on the index page, which linked to a file of 4 colour photos showed students' reading scenes in classrooms. Two school library home pages provided the floor plans of their libraries along with their locations on the campus map. Another school Website provided the size of library book stock under the heading of library status. 
Four senior high schools in Tokushima city provided library home pages. One of them was the Website presented by Johnouchi High School (Senior and Junior combined), which had been already introduced in former section of this paper.

The most elaborate Website among the 4 just mentioned above was offered by Tokushimakita Senior High School which contained information such as (1)library guide, (2) library floor plan, (3library events, (4)weekly book talk, (5)library holdings, (6) usage statistics, and (7)popular books. By clicking these 7 headings on the top page of library home page, users are able to open each 7 sub-sites or lower level files. Information provided on such subsites is as follows:

\section{Library Guide;}

- Library hours, loan procedures, rules for Internet search, reference services, and library manners.

\section{Library Floor Plan.}

* Return button to the top

By moving the mouth pointer to any desirable spot on the floor map, users are able to view the color photos of the pointed spot with some explanations.

* Return button to the top

\section{Library Events}

- Announcement of library calendar during winter vacation

- Announcement of Asa-dokusho program in coming school semester

* Return button to the top

$\diamond$ Weekly Book Talk: Publicizes speakers of each book talk meeting with its theme and book titles to be introduced. At the weekly meting, subject teachers as well as teacher librarian would take parts as speakers.

* Return button to the top

Library Holdings (as of April 1, 2006)

- Books (19,537 volumes) tabulated by 10 main classes of NDC

- Newspapers (3 titles); Daily subscribed issues and the back files of past 3 years

- Video cassette tapes (30 tapes)

- Sets of books organized for reading circle meeting (30 sets)

*Return button to the top

\section{Usage Statistics}

- Monthly data tabulated by categories of book loans, library visitors, and library opening days

- Graphic presentation of above monthly data

- Subject analysis of loaned books

- Pie graph presentation of annual loan data divided by 10 main classes of NDC

* Return button to the top

Popular Books; monthly ranking of the top 3 loaned books from the library, listed with titles, authors, and annotations or short book review

* Return button to the top

Other library home pages appeared on the Web is constructed by 2 senior high schools in Tokushima city; one is prefectural and the other is municipal. The contents of these 2 Websites were quite simple and informative in nature. Both provided the library guide with seating capacities and available equipments such as computers and videocassette recorders. 
It can be concluded that senior high school library home page is much simpler and more informative as compared with junior high school library home page. It carries less colour photos, videos, and clipart. The nature of its content is almost the same as junior high school Websites, because both put the most emphasis on reading guidance and its promotion.

\section{NATIONAL FOCUS STUDY}

Eliminating the Websites reviewed already, the total of 117 school library Websites were examined for this national focus survey. These Websites were provided by 28 junior high, 33 integrated junior/senior high, and 56 senior high schools respectively. They were sampled from the schools, which spread all over Japan from Hokkaido in the north to Kagoshima Prefecture in the south. In the following, the analysis and evaluation of their contents will be explained in order of school levels.

\section{JUNIOR HIGH SCHOOLS}

The sampled 28 school library home pages on junior high school level were carried by one national, one private, and 26 public schools. Out of 26 schools, 22 were municipal, and the rest of 4 were township schools. In a way of defining the contents of sampled school library home page by their functions, all terms appeared on the index of Websites were listed and arranged in order of applied frequency.

In the process of listing index terms, it was found that there were 6 schools of which library Websites were made of one page or the home page with no windows to open to further files by clicking index icons. Generally speaking, the contents of such one page Website were mostly library introduction as well as library user's guide, e.g. library hours, circulation rules, and new acquisition lists of library materials. The index terms on the top page of remaining 22 Websites were listed below in order of use frequency. The figure that placed at the head of each term indicates the total number of school library Websites that used the term on the index.

\section{The Frequency Ranking of Index Terms on Library Websites}

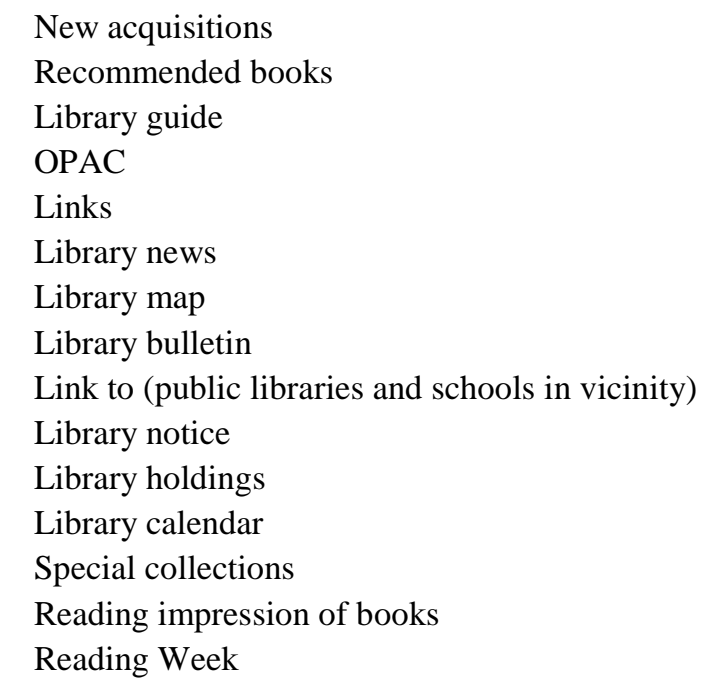

\author{
1 Monthly exhibits \\ 1 Library volunteers \\ 2 Favourite book ranking \\ 2 Asa-dokusho \\ 2 Learning activities \\ 1 Library circumstance \\ 1 Library Q \& A \\ 1 From the librarian \\ 1 Topics \\ 1 Subscribing magazines and newspapers \\ 1 Student library committee \\ 1 Library hours \\ 1 Quiz \\ 1 Palaeography reading
}


By viewing the above list, the tendency to emphasize more informative contents on the occasions of library home page building became clear. The top ranking terms on the use frequency list were the terms that imply basic information for school library users. There were few terms that suggested instructive functions. The icon "palaeography reading" which connotes instructive activity had only connected to the announcement of palaeography reading hour in the school library room. The index term "Favourite books ranking" was linked to the listing of book titles that were loaned by many students from the library. "Recommended books" icon opened to the files of recommended books by teachers, librarians and fellow students.

The most instructive content was indexed by the term "Links" which directly linked from library home page to the Website of search engines, electronic dictionaries, databases, different levels of libraries and information agencies, and the governments on global, national, and local levels. This is the function only possible by the use of Websites. However, the conducts of preliminary orientation by teachers and school librarians are the prerequisite for the effective use of link collections.

Another instructive content was headed by the term "Quiz". The Website of Iida Municipal Midorigaoka Junior High School in Nagano Prefecture was the only one example of this case. (http://www.midorijh.ed.iidanet.jp/tosho/library.htm)

Strangely enough, there were 2 different library Websites that carried only the texts of research papers by teacher librarians respectively. The papers contained the hypnoses of effective library skills instruction, the curriculum of different teaching subjects in relation to school library use, and annual schedule of such instructions. The intensions to carry such research papers on particular school library home page were not clear.

\section{Integrated Junior/senior High Schools}

The total of 33 library home page were collected and reviewed. These 33 were consisted of 3 public (prefectural) and 30 private schools. The private schools were all located in metropolitan areas of Tokyo, Nagoya, and Osaka. The structure of some Websites reviewed here were more complex than that of junior high schools, because ID number and/or login password were required to open particular windows, such as "OPAC", "search engines", and "requests \& reservations", on the library Websites.

Applying same process of junior high school survey, the terms placed on the library Website index were listed in order of appearing frequency. The total of terms on the index was 61, and this total was doubled to 31 terms of junior high school Websites. However, some terms were synonymic each other. Adding to this, 16 terms out of $61(26.2 \%)$ were overlapped with the terms on the index of Junior high school library Websites. Furthermore, the top 6 ranking terms on the frequently list were same as that of junior high school library Website. Such facts mentioned above led the author to the assumption that the contents of library Websites were almost the same on junior and integrated junior/senior high school levels.

The following terms on library Website index seem to imply the instructive contents for information literacy development. They are "book classification system", "how to search library materials", "how to use OPAC", "instruction for information literacy", "information 
skills for resource based-learning", "supports for class work", "supports for reading \& searching", and "software usable at school library".

The most highly evaluated contents of library home page from the viewpoint of information literacy instruction were found at the Websites of (1)Konan Boys' High School, (2) Osaka Jogakuin (Girls') High School, and (3)Tezukayama Gakuin High School. These 3 integrated junior/senior high schools are all affiliated to 3 universities in Osaka metropolitan area respectively.

\section{Senior High Schools}

The total of 56 library home page reviewed here was carried by 8 private schools, and 48 public senior high schools. Out 48 public schools, 45 are prefectural and 3 are municipal. Although all private schools offer general course programs, public schools are comprised of 42 general, 3 commercial, and 3 technological high schools. There was not much difference between general and vocational schools with reference to library home page contents.

Out of 60 terms found on the library Website index, 18 terms (30\%) were overlapped with the terms on junior high school library Website index, and 20 terms (33.3\%) with those on integrated school Website index. Judging from the index terms, unique features of senior high school Websites were as follows: (1) provision of the document text related to school library, e.g. Library Bill of Rights, School Library Law, and School Library Manifest, (2) adoption of interactive function with library, such as library Web log and mail box to the librarian, (3) elaborative link collection, (4) preparation of subject bibliographies on teaching units, assigned study theme, the human rights, and ecological education, and (4) extensive reports on student library activities, such as library exhibits, library events, outreach service to nursery schools and senior citizen's homes.

All schools reviewed here carried library publications, e.g. library newspapers and bulletins on the Web. Some school library Websites only provided library bulletins, of which contents were varied from user's guide to book reviews and activity reports.

The significant feature of senior high school library home page was the student's active participation in the management and maintenance of library Website through updating and uploading.

Nagano Prefectural Iida Senior High School Library carried the best school Library Website from instructive point of view. The components of this Website are (1) OPAC (Limited on school intranet), (2) link collections relating to academic and career counselling, ecology, and book selection and buying, (3) student's guide for resource-based learning, (4) library user's guide, and (5) information of libraries and educational institutions. All files of library announcements and every issue of school library news and bulletin ever published are available on the Internet. This library home page is updated every day.

\section{FINDINGS AND COMMENTS}


Through the review and analysis of school library home page and e-communication with teachers and librarians, the hypothesis of this study were partly confirmed. The followings are the summary of findings and comments:

- There was not much difference in the functions of library home page by school level in Japanese secondary education. The contents were informative, cultural and instructive in function.

- The structure of library home page did not closely relate to school levels. The percentages of the simple structure (e.g. one-page Website) among the survey samples were $21.4 \%$ at junior high, $27.2 \%$ at integrated junior/senior high, and 26.6\% at senior high school level.

- The contentwise, the most instructive library home page was carried on the integrated junior/senior high school level, while senior high schools provided the most resourceful Website.

- The usability of library home page depended largely on the placement of "return to top" and "link to" buttons on each Webpage.

- The most useful and instructive feature of library home page was the adoption of "links" which directly connected the users to search engines, electronic dictionaries, appropriate databases, relevant educational institutions, government agencies, and information services.

- The contents of school library home page exactly reflected the recognition of library function by school administrators and faculty members. The function of school library is generally understood as a "Reading Center", rather than the place to instruct the skills of information search and retrieval.

- The contents also reflected the tendency to put more emphasis on reading guidance than information literacy development in Japanese secondary school library.

- The contents were strongly influenced by the expected targets or home page users. If schools need to attract the interest of future students and parents, the contents would be more informative than instructive. This was proved by the cases of Tokyo Metropolitan Senior High Schools and some private institutions.

- The contents had illustrated the popularity of Asa-dokusho, the special feature of Japanese reading guidance in schools.

- It became clear that the responsibility of teacher-librarian and school librarian as the school net master was not yet established at this moment, and hardly recognized by school administration. There were many sample home pages of which contents have not been updated for more than several years.

- It is definite that the purpose of school library home page is dual, e.g. informative and instructive. Informative function would be demonstrated by the adoption of bulletin board system (BBS), while instructive function could be performed by applying AR programs, preparing various bibliographies on teaching subjects, and carrying path finding readings such as commentary of reference books or articles that help to proceed of resource-based learning and independent study.

- The review of school library home page led the author to present a model or framework of standard school library home page.

- The possibility to utilize library home page as an instructional tool for information literacy development was proved, but its effectiveness was not verified by this study.

- Further studies are needed to verify the instructive effectiveness of school library home page through the examinations of academic performance by the students who have frequently used school library home page. 


\section{CONCLUSIONS}

The majority of well-designed library home pages with resourceful contents were carried by prestigious schools where highly oriented instructions toward preparation for upper school or university education were practiced. This fact suggests that school library Website can be used as a yardstick or a standard to appreciate and evaluate the quality of library service as well as school itself. Also this fact proves that well designed library home page help students to develop their study skills or information literacy.

On the other hand, the wide surfing of school library Websites revealed that not all schools seemed to have the definite intension to foster and improve the student's information literacy through the provision of library home page at this moment. Therefore, the further research is necessary to verify the effectiveness of library home page as an instructional tool of information literacy development. The suggested measures for further study are on-thespot investigation of library service through observations, questionnaires, and interviews, and the comparison of academic performance between the students who frequently open the windows of library home page and those who do not.

\section{Author Note:}

Mieko Nagakura, Instructor of Soka University in Tokyo, Japan, has published many articles and books at national and international levels. She has taught at Tokyo Gakugei University and Jissen Women's University as the Professor of Library Science. For IASL, she had served the Regional Director for Asia for 4 terms (1981-87, 1993-99). Presently she is contributing to school librarianship as the Vice President of Japan Society of School Library Science. 